\title{
Genome-wide association studies identify new melanoma susceptibility loci
}

\author{
Tadeusz Dębniak \\ From Annual Conference on Hereditary Cancers 2011 \\ Szczecin, Poland. 17-18 November 2011
}

\begin{abstract}
We report results of the genome-wide association studies for melanoma that were conducted by the GenoMEL Consortium. In the first study 2981 individuals with melanoma and 8408 study-specific control individuals of European ancestry were analysed, in the second experiment 2168 Australian individuals with melanoma and 4387 control individuals were genotyped for 317,000 or 610,000 singlenucleotide polymorphisms (SNPs). Three of the previously reported melanoma susceptibility loci (MC1R, ASIP and CDKN2A) reached genome-wide significance in both studies. Three new loci were found to be associated with melanoma risk in European GWAS: rs1801516 in ATM, rs45430 in MX2, rs13016963 in CASP8. A fourth locus near CCND1 remains of potential interest. An Australian GWAS identified a new susceptibility locus at 1q21.3 (rs 7412746) and potentially 1q42.12 (rs3219090). Further studies will be required to determine which gene or genes at the reported loci mediate melanoma risk.
\end{abstract}

Published: 20 April 2012

doi:10.1186/1897-4287-10-S3-A5

Cite this article as: Dębniak: Genome-wide association studies identify new melanoma susceptibility loci. Hereditary Cancer in Clinical Practice 2012 10(Suppl 3):A5

Correspondence: debniak@sci.pam.szczecin.pl

Pomeranian Medical University, Clinic of Oncology, Szczecin, Poland

Submit your next manuscript to BioMed Central and take full advantage of:

- Convenient online submission

- Thorough peer review

- No space constraints or color figure charges

- Immediate publication on acceptance

- Inclusion in PubMed, CAS, Scopus and Google Scholar

- Research which is freely available for redistribution 